\title{
L'épique médiéval et le mélange des genres (Actes réunis par Caroline Cazanave)
}

\section{Maria Colombo Timelli}

\section{(2) OpenEdition}

1 Journals

\section{Édition électronique}

URL : http://journals.openedition.org/studifrancesi/9801

DOI : 10.4000/studifrancesi.9801

ISSN : 2421-5856

Éditeur

Rosenberg \& Sellier

\section{Édition imprimée}

Date de publication : 1 octobre 2007

Pagination : 421

ISSN : 0039-2944

\section{Référence électronique}

Maria Colombo Timelli, «L'épique médiéval et le mélange des genres (Actes réunis par Caroline

Cazanave) », Studi Francesi [En ligne], 152 (LI | II) | 2007, mis en ligne le 30 novembre 2015, consulté le 09 janvier 2021. URL : http://journals.openedition.org/studifrancesi/9801 ; DOI : https://doi.org/ 10.4000/studifrancesi.9801

Ce document a été généré automatiquement le 9 janvier 2021.

\section{(c)}

Studi Francesi è distribuita con Licenza Creative Commons Attribuzione - Non commerciale - Non opere derivate 4.0 Internazionale. 
L'épique médiéval et le mélange des genres (Actes réunis par Caroline Cazanave)

Maria Colombo Timelli 


\section{RÉFÉRENCE}

L'épique médiéval et le mélange des genres (Actes réunis par Caroline Cazanave), Besançon, Presses Universitaires de Franche-Comté, 2005 («Littéraires»).

1 Actes du Colloque qui s'est déroulé à l'Université de Franche-Comté en octobre 2002. Deux contributions ont pour objet le Roman de Guillaume d'Orange en prose (éd. par M. Tyssens, N. Henrard et L. Gemenne, Paris, Champion, 2000: cf. «SF», n. 137, pp. 423-424; les tomes II et III ont paru en 2006).

Damien DE CARNÉ (Le prologue du "Guillaume en prose", pp. 167-180) propose une lecture ponctuelle du prologue de la version en prose $\mathrm{du} \mathrm{xv}^{\mathrm{e}}$ siècle: si quelques éléments (appel à l'attention de l'auditoire, références à l'oralité, mention de Dieu) dérivent en droite ligne du prologue-type de la chanson de geste, d'autres (référence à une source écrite, présence de l'auteur, attention portée à la composition du texte) montrent au contraire le glissement d'un genre littéraire - la chanson de geste - à un autre - le roman.

3 Nadine HENRARD (L'épisode de Clarisse et Esmérée dans le "Roman en prose de Guillaume d'Orange", pp. 181-197) analyse l'épisode narré aux chapitres 114-119 du roman en prose, épisode qui n'a pas d'équivalent dans les chansons en vers conservées. Sans avoir recours à l'hypothèse d'une épopée perdue, il est possible d'admettre que le prosateur a fait œuvre d'auteur en réunissant des données puisées dans divers endroits du cycle. Ce fragment narratif, dont les protagonistes sont deux femmes, est particulièrement représentatif du mélange des genres: en soignant la description psychologique, en faisant une large part aux sentiments amoureux, l'auteur crée un épisode qui tient plus du roman d'aventures que de l'épopée. 